\title{
Dimensions of the 'Body' in Tranquility Meditation
}

\author{
Bhikkhu Anālayo ${ }^{1}$
}

Accepted: 19 May 2021 / Published online: 10 July 2021

(c) The Author(s) 2021

\begin{abstract}
A perusal of selected forms of early Buddhist tranquility meditation brings to light the complexity of the roles assumed by the Indic term kayya, usually translated as "body," which corresponds to the domain of the first establishment of mindfulness. The present exploration of such complexity, which proceeds in critical dialogue with positions taken by Eviatar Shulman, covers the significance of the supernormal feat of conjuring up a mind-made body, the mindful contemplation of the somatic dimensions of absorption attainment, and the transition from these to the immaterial spheres. The patterns of early Buddhist thought that emerge in this way make it preferable to understand the compass of the term kāya to cover a continuum of somatic experiences that can range from gross materiality to more subtle types of embodiments. Even immaterial experiences, based on the complete transcendence of materiality, can still be conceptualized with the help of the term kāya in a phrase that serves to convey direct and personal experience.
\end{abstract}

Keywords Absorption $\cdot$ Body $\cdot$ Contemplation of the Body $\cdot$ Embodied Mindfulness $\cdot$ Immaterial Spheres $\cdot k \bar{a} y a \cdot$ Mindmade Body

In the traditional Buddhist setting, the cultivation of mindfulness takes the form of four establishments of mindfulness, the first of which is concerned with the body. The Pāli and Sanskrit term $k \bar{a} y a$, here rendered as "body," can in other contexts have a more general sense of a "group." An example for such usage occurs in the context of an analysis of craving:

Monastics, and what is craving? Monastics, there are these six groups of craving: craving for forms, craving for sounds, craving for odors, craving for tastes, craving for tangibles, and craving for mental objects. (SN 12.2: katamā ca, bhikkhave, tanhhā? chayime,

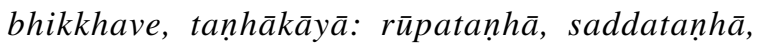
gandhatanhhā, rasatanhhā, phoțthabbataṇhā, dhammatanh $\bar{a})$.

What is called craving? It is reckoned to be the three groups of craving: sensual craving, craving for becoming, and craving for annihilation.

\section{Bhikkhu Anālayo}

1 Barre Center for Buddhist Studies, 149 Lockwood Road, Barre, MA 01005, USA
(EĀ 49.5: 云何名爲愛? 所謂三愛身是也: 欲愛, 有 愛, 無有愛).

Although the parallels offer different modalities of defining craving, with the Pāli version opting for an analysis by way of the six sense objects and its Chinese parallel employing a threefold distinction (found also in other Pāli discourses), the two versions translated above agree in employing the term "group" ( $k \bar{a} y a /$ 身) to introduce their respective presentations. In such a context, the rendering "body" would fail to make sense.

When the same term kayya does refer to the body, according to Rhys Davids and Stede (1921/1993, p. 207) two interrelated senses can be discerned:

Kāya under the physical aspect is an aggregate of a multiplicity of elements which finally can be reduced to the four 'great' elements, viz. earth, water, fire, and air ... it is built up and kept alive by cravings, and with death it is disintegrated into the elements ... Kāya under the psychological aspect is the seat of sensation ... and represents the fundamental organ of touch which underlies all other sensation.

As far as the average experiences of human beings are concerned, the "body" made up of the four elements corresponds to the "body" as the seat of sensation and the 
experience of touch. Nevertheless, the same does not necessarily hold during advanced stages of meditation. Although with a range of mindfulness practices the physicality of the body will naturally be in the foreground, other forms of practice can lead to the emergence of dimensions of the body that are no longer related to the four elements. Moreover, the early discourses at times even employ the same term "body" for a form of meditative "touching" that transcends materiality.

\section{The Mind-made Body}

An example illustrative of a usage of the term "body" in a meditative context that goes beyond the four elements is the description of a supernormal feat which, according to early Buddhist thought, becomes possible for an adept in meditation who has mastered the four absorptions. A description of the feat in question can be found, for example, in the Sāmaññaphala-sutta and its parallels:

From this body, [the meditator] conjures up another body, which has form, is mind-made, and is endowed with all limbs and parts, not lacking any faculty.

(DN 2: so imamhā kāyā añ̃am kāyam abhinimmināti rūpim manomayam sabbañgapaccaingim ahīnindriyaṃ).

From that body, through mental arousal [the meditator] conjures up another body, which is endowed with form, mind-made, and complete, not lacking any faculty.

(Gnoli, 1978, p. 245 tasmāt kāyāt mānasam vyutthāpyānyam kāyam abhinirmimīte rūpinam manomayam avikalam ahīnendriyam).

From within [the meditator's] own material body, [made up of] the four elements, through mental arousal [the meditator] conjures up a conjured body with all faculties and limbs complete.

(DĀ 27, supplemented from DĀ 20: 從已四大色身中, 起心化作化身,一切諸根, 支節具足).

I will establish a body that is mind[-made], conjuring up the manifestation of various bodies that are immaterial and mind[-made], endowed with shape, with all faculties undamaged, through concentrative arousal conjuring up diversified bodies that are endowed with shape. (T22: 我當立身心, 化現眾身, 無有色心, 具足形容, 諸 根無毀, 從三昧起化若干身, 形容具足).

In the present context, the expression "mind-made" is best understood to convey the sense that such a body is a mental one, in the sense of consisting in and being "made of" mind (De Notariis 2018). Hamilton (1996, p. 163) reasoned that "“normal' bodies are gross rüpa [material form], whereas the mind-made body is subtle rūpa. This is true whether the manomaya body is one in which one is reborn as a result of having attained a certain level of meditation in a previous life, or whether the manomaya body is deliberately created in this life." Indeed, as pointed out by Lee (2014, p. 69), mastery of absorption and the "creation of a manomaya-kāya may be understood not just as aspects of a practitioner's spiritual advancement in this life, but also as their existential transformation to a higher cosmological level in the next life." Harvey (1993, p. 36) explained that the above type of description implies the following:

consciousness is seen as able to leave the physical body by means of a mind-made body. Such a body is seen as a kind of 'subtle body,' for a being with a mind-made body is said to feed on joy (D.I. 17), not on solid nutriment (D.I. 195). It thus lacks the four great elements of the physical body ... the subtle matter composing it can only be visible and audible matter (Vibh. 405). However, the mindmade body is invisible to the normal eye (Pați. II. 209). It occupies space, but does not impinge on gross physical matter ... With such a body, a person can exercise psychic powers such as going through solid objects, being in many places at once, or flying (D.I. 78).

The belief in the possibility of performing such a feat appears to have been a common notion in the ancient Indian setting (De Notariis 2019a, 2019b). Beyond the Indian setting, according to Swearer (1973, p. 448) the Buddhist descriptions of such abilities, including the production of a mind-made body, "have striking similarities with the archaic phenomenon of shamanism." The same notion of a mental body also appears to stand in the background of some conceptions of supernormal feats like levitation (Anālayo 2016, 2021). In other words, when the early discourses report the Buddha or some of his adept disciples visiting a particular heaven to converse with its inhabitants, such accounts probably originated from the idea of travelling with the mind-made body.

A relevant passage describes how a meditator performs one in the standard list of supernormal feats, involving touching the orbs of the sun and moon with the hands, while at the same time remaining seated in the hermitage (Schlingloff 2015, p. 90 n. 3). Another passage indicates that travelers in space, who lose the state of absorption, will simply find themselves back on the seat of meditation (Clough 2012, p. 85). Such descriptions convey the idea that the mind-made body was considered to have been extracted from the actual physical body, enabling the practitioner to perform feats and travel to various realms with the former while the latter continues to be seated in meditation.

Ostensibly unaware of the above-mentioned publications, relevant to the topic of the mind-made body and its implications, Shulman (2021, p. 14) considered the presentation in the Sāmañ̃aphala-sutta to imply that "an apparently material body is the product of a mental attainment in advanced meditation" adding (note 76) that "the overall description seems to take 
this as a regular body, as is confirmed by the ... acceptance that this body possesses all limbs and faculties." Yet, in early Buddhist thought various celestial beings are considered to be endowed with limbs and faculties, even though these beings are not conceived as having material bodies made up of the four elements, in this respect differing from humans and animals. Appreciating the ancient Indian notion of the mind-made body requires taking these cosmological aspects into account.

\section{The Body in Absorption}

The role of the body in relation to absorption attainment can be explored based on the Discourse on Mindfulness of the Body, an exposition that covers the same domain as the first establishment of mindfulness. This discourse includes in its purview the bodily dimension of the experience of absorption (Anālayo 2014, p. 34; 2017 p. 56; 2019 p. 2350; and 2020 p. 1522). The relevant passages in the Pāli and Chinese versions, which describe one out of several modalities of contemplation of the body, proceed as follows for the case of the first absorption:

Secluded from sensual desires and secluded from unwholesome states, with application and sustaining, with joy and happiness born of seclusion, one dwells having attained the first absorption. One drenches, pervades, saturates, and suffuses this very body with joy and happiness born of seclusion, such that there is no part of the whole body that is not touched by the joy and happiness born of seclusion.

(MN 119: vivicc' eva kāmehi vivicca akusalehi dhammehi savitakkam savicāram vivekajam pītisukham pațamam jhānam upasampajja viharati. so imam eva kāyam vivekajena pītisukhena abhisandeti parisandeti paripūreti parippharati, nāssa kiñci sabbāvato kāyassa vivekajena pītisukhena apphuțam hoti).

One soaks the body, moistens, and completely pervades it with joy and happiness born of seclusion, [so that] within this body no part is not pervaded by joy and happiness born of seclusion.

(MĀ 81: 離生喜樂漬身, 潤澤, 普遍充滿, 於此身中, 離生喜樂, 無處不遍).

A notable difference here is that the Chinese version does not describe the actual attainment of the first absorption and instead just covers its somatic effect. In the present context, this appears to be the more plausible presentation, as "it is not the attainment of jhanna as such, but rather the bodily experience caused by jhanna that comes under the heading of mindfulness of the body" (Anālayo 2011, p. 674). Comparison with the Chinese version thus enables putting into perspective the assessment by Shulman $(2021$, p. 8$)$ that the Pāli version "now proceeds to describe the attainment of the four jhānas, including them within mindfulness directed to the body." In other words, it is more specifically the somatic effect of absorption that here falls within the purview of mindfulness directed to the body.

Since Shulman (2021, p. 16) lists Anālayo (2011) among the works consulted, it is at first sight unexpected that the significant perspective provided by the Chinese parallel is not taken into account. The author's list of references also includes Kuan (2008) who, in an appendix to his study, provided a translation of this Chinese parallel. However, not taking into consideration this parallel extant in Chinese could reflect an assessment given by Shulman (2021, p. 4 n. 14) of the value of consulting Chinese Ágama discourses, expressed in the following manner:

Issues of comparison with other extant versions of the early discourses may reveal interesting insights, but should not be thought to bring us closer to the historical realities of early Buddhism. Each textual tradition offers its own version(s) of discourses, which conform to local tastes and standards. Thus, we could read Chinese versions of Suttas in order to understand ideals of masculinity in early Chinese Buddhism, not in order to return to the days in which the texts were composed.

This assessment involves a substantial misunderstanding. The situation of early discourses preserved in Chinese translation could be illustrated with the example of Luther's translation of the Bible into vernacular German in the sixteenth century. This act of translation did not result in turning the content of the Bible into a reflection of medieval German ideals. Be it in German or any other translation, the Gospels could still be employed in an attempt "to return to the days in which the texts were composed," by way of trying to discern between a common core and later additions.

The same holds for the Chinese Ägamas. These are predominantly testimonies of ancient Indian thought, not of Chinese culture. In fact, the Madhyama-āgama in question was translated by the Indian Gautama Sanghadeva into Chinese (Anālayo 2015). His translation style shows a marked concern with staying truthful to the Indic original (Radich \& Anālayo 2017, p. 218). It follows that the Madhyama-āgama is as much a testimony to early Buddhism as its Pāli parallel, the Majjhima-nikāya. Therefore, indications that can be gathered from comparative study of the Madhyama-āgama collection deserve to be taken seriously.

In sum, the idea of "the body" in the context of the above instance of mindful contemplation concerns the somatic repercussions of absorption attainment. These should be understood to involve a pervasion and suffusion of the body 
with the joy and happiness resulting from the concentrated state of the mind that has entered absorption.

Subjective meditative experiences in early Buddhist thought come closely interwoven with cosmology (Gethin 1997), to the extent that an absorption experience has a counterpart in a particular celestial realm and is expected to conduce to rebirth in that realm. Since the realms corresponding to the four absorptions are considered to be fine-material, it seems that the indication gathered from the notion of the mind-made body holds here as well, in the sense that the reference to the body needs to be understood by keeping its cosmological counterpart in mind. In other words, the idea could well be that, "in the case of absorption attainment, the way the presence of the body is sensed would be much more refined and of an altogether different type compared to how the body is experienced as a sensedoor during normal everyday life" (Anālayo 2017, p. 55).

\section{The Formless Attainments}

In early Buddhist thought, mastery of the four absorptions forms the basis for a variety of meditative accomplishments, one of them being the above-mentioned conjuring up of a mind-made body. Alternatively, the same degree of mastery can be employed to attain the immaterial spheres. The transition from the fourth absorption to the first of these immaterial spheres takes the following form:

Completely passing beyond perceptions of form, with the disappearance of perceptions of resistance, without attending to perceptions of diversity, [attending instead to] 'infinite space,' one dwells having attained the sphere of infinite space.

(MN 25: sabbaso rūpasañ̃̃ānam samatikkamā pațighasañ̃̄ānam atthaingamā nānattasañ̃̄ānam amanasikārā ananto ākāso ti ākāsānañcāyatanam upasampajja viharati).

By completely transcending perceptions of form, with the cessation of perceptions of resistance, not being aware of perceptions of diversity, [being instead aware of] 'infinite space,' one dwells in the accomplishment of the sphere of infinite space.

(MĀ 178, supplemented from MĀ 97: 度一切色想, 滅 有對想, 不念若干想, 無量空, 是無量空處成就遊).

The above description indicates that all experiences related to materiality are left behind at this stage. Nevertheless, the term "body" can still be used in relation to such attainments. This takes the form of a specific phrase that literally means "having touched with the body" (e.g. MN 70: kāyena phusitvā/phassitvā and MĀ 195: 身觸), used in relation to the immaterial spheres (and at times even in relation to Nirvana; see Dhammadinnā 2021, p. 109). As clarified by Schmithausen (1981, p. 214), this phrase "presumably intends immediate personal experience." Along the same lines, Radich (2007, p. 263) reasoned that "to 'touch $\mathrm{X}$ with the body' may be a rough analogy to figures of speech like e.g. English 'know it in your bones' ... meaning 'to know directly and certainly from personal experience."' In this way, when applied to the immaterial spheres, the occurrence of the term kāya in the phrase under discussion conveys the sense of involving the whole of one's personal experience (Anālayo 2011, p. 379).

In contrast to these assessments, Shulman (2021, p. 10) rather argued that "some authors or practitioners saw the body as related to the attainment of the following four 'formless attainments.' In a recurrent formula we find a meditator who 'abides having touched those quiet deliverances that are formless, having surpassed form, with his body." This reasoning then led to the conclusion that even "these accomplishments clearly seem to be embodied, tangible, and concrete" (p. 10).

The list of references consulted by Shulman (2021, p. 16) includes, besides Anālayo (2011), also Radich (2007) and Schmithausen (1981). Since in this case the indications regarding the sense conveyed by the phrase under discussion do not involve Chinese parallels, it is difficult to conceive of a cogent reason why the opinions expressed in these works have neither been mentioned nor taken up for criticism.

The unconvincing nature of the reasoning resulting from not taking into account relevant scholarship can be seen in the assumption by Shulman (2021, p. 10 n. 52), in a note appended to the above reference to "embodied, tangible, and concrete" accomplishments, that another occurrence of this phrase in relation to the five faculties (of confidence, energy, mindfulness, concentration, and wisdom) implies that an arahant "abides having touched them with the body." How does one touch the faculty of mindfulness, for example, with the body?

Shulman (2021, p. 3) had introduced his discussion with the announcement that his "study aims to unearth the positive role attributed to the body in seminal contexts of the Buddhist path to liberation," apparently unaware of the fact that this has already been covered in Anālayo (2014), a publication quoted in Langenberg (2018) which in turn has been quoted twice by Shulman (2021, p. 2 and p. 8 n. 39). Together with the case mentioned above, it seems as if the author quoted publications he had not fully read.

This impression finds confirmation when Shulman (2021, p. 1) expressed his wish to go beyond a supposedly common interpretation, according to which "the body is not deemed essential to awakening and is considered tangential at best," followed by providing support for his assessment of the existence of such an interpretation in his first footnote in this way: "That this approach continues to be influential, beyond many of the classic studies referred to below, can 
be seen is [sic] such studies as Anālayo (2012, p. 307), who emphasizes 'liberation of mind and liberation by wisdom'."

The only occurrence of the quoted phrase on the cited page features in the context of a survey of similes illustrating the nature of liberation. The summary of the relevant passages takes the following form in Anālayo (2012, p. 307): "One who has reached liberation of the mind and liberation by wisdom has lifted up the crossbar; has filled the moat; uprooted the pillar; withdrawn the bolts; lowered the banner; dropped the burden and is unfettered."

The quoted passage does not express any consideration of the role of the body as tangential (or not tangential) to awakening at all, as it is about something quite different. The expression "liberation of the mind and liberation by wisdom" in turn is simply a standard way of referring to full awakening in the early discourses and carries no implication about the role of the body for such matters. Nevertheless, Shulman (2021, p. 2 and note 6) referred back to this first footnote in an assessment of "traditional interpretations" which, in his view, overlook the fact that the gaining of liberation "relates to the experience, in the body and the mind, of people who lived to tell the tale; otherwise, we would have never heard of it." It seems almost as if he believed that other scholars denied the relevance of the body to liberation to such an extent as to overlook that a fully awakened one still has a body. All of this makes it difficult to avoid the impression that the presentation in Shulman (2021) is not based on a proper consultation of previous academic research.

Contrary to the views expressed by Shulman (2021), the conception of the mind-made body in early Buddhist thought intends a mental rather than a material body; contemplation of the body as a mindfulness exercise concerns the somatic repercussions of absorption rather than just the attainment itself; and the idiomatic phrase "touching with the body" is best understood to convey the sense of a personal and direct experience with one's whole being. The three dimensions of the body surveyed here converge on showing the complex implications which the term for the "body," kāya, can carry in its usage in the early discourses.

Abbreviations DĀ: Dīrgha-āgama (T 1); DN: Dīgha-nikāya; EĀ: Ekottarika-āgama (T 125); MĀ: Madhyama-āgama (T 26); MN: Majjhima-nikāya; SN: Samyutta-nikāya; T: Taishō edition

Funding Open Access funding enabled and organized by Projekt DEAL.

\section{Declarations}

Ethical Approval This article does not contain any studies performed by the author with human participants or animals.
Conflict of Interest The author declares he has no conflict of interest.

Open Access This article is licensed under a Creative Commons Attribution 4.0 International License, which permits use, sharing, adaptation, distribution and reproduction in any medium or format, as long as you give appropriate credit to the original author(s) and the source, provide a link to the Creative Commons licence, and indicate if changes were made. The images or other third party material in this article are included in the article's Creative Commons licence, unless indicated otherwise in a credit line to the material. If material is not included in the article's Creative Commons licence and your intended use is not permitted by statutory regulation or exceeds the permitted use, you will need to obtain permission directly from the copyright holder. To view a copy of this licence, visit http://creativecommons.org/licenses/by/4.0/.

\section{References}

Anālayo, Bh. (2011). A comparative study of the Majjhima-nikāya. Taipei: Dharma Drum Publishing Corporation.

Anālayo, Bh. (2012). Excursions into the thought-world of the Pāli discourses. Washington: Pariyatti.

Anālayo, Bh. (2014). Perspectives on the body in early Buddhist meditation. In K. Chuang (Ed.), Buddhist meditative traditions: their origin and development (pp. 21-49). Taipei: Shin Wen Feng Print.

Anālayo, Bh. (2015). Āgama/Nikāya. In J. Silk, O. von Hinüber, \& V. Eltschinger (Eds.), Brill's encyclopedia of Buddhism (pp. 50-59). Leiden: Brill.

Anālayo, Bh. (2016). Levitation in early Buddhist discourse. Journal of the Oxford Centre for Buddhist Studies, 10, 11-26.

Anālayo, Bh. (2017). Early Buddhist meditation studies. Barre: Barre Center for Buddhist Studies.

Anālayo, Bh. (2019). The role of mindfulness in the cultivation of absorption. Mindfulness, 10(11), 2341-2351. https://doi.org/10. 1007/s12671-019-01206-7

Anālayo, Bh. (2020). Somatics of Early Buddhist Mindfulness. Mindfulness, 11(6), 1520-1526. https://doi.org/10.1007/ s12671-020-01382-x

Anālayo, Bh. (2021). The mind-made body and levitation: a brief clarification. Annali Di Ca'Foscari, Serie Orientale, 57, 39-40.

Clough, B. S. (2012). The cultivation of yogic powers in the Pāli path manuals of Theravāda Buddhism. In K.A. Jacobson (ed.) Yoga Powers, Extraordinary Capacities Attained Through Meditation and Concentration (pp. 77-95). Leiden: Brill.

De Notariis, B. (2018). Osservazione sull'esposizione della creazione del corpo fatto di mente (manomaya-kāya) all'interno del Sāmaññaphala-sutta. Annali Di Ca' Foscari, Serie Orientale, 54, 177-204. https://doi.org/10.30687/AnnOr/2385-3042/2018/01/ 009

De Notariis, B. (2019a). The concept of manomaya in early Buddhism and Upanișads: a study with particular reference to the Pāli Sīlakkhandhavagga. Journal of the International Association of Buddhist Studies, 42, 47-81. https://doi.org/10.2143/JIABS. 42.0.3287477

De Notariis, B. (2019b). The Vedic background of the Buddhist notions of iddhi and abhiññā, three case studies with particular reference to the Pāli literature. Annali Di Ca' Foscari, Serie Orientale, 55, 227-263. https://doi.org/10.30687/AnnOr/2385-3042/2019/01/008

Dhammadinnā, Bh. (2021). Reflections on truth and experience in early Buddhist epistemology. In C. Roloff, W. Weisse, \& M. Zimmermann (Eds.), Buddhism in dialogue with contemporary societies (pp. 101-133). Münster and New York: Waxmann.

Gethin, R. (1997). Cosmology and meditation: from the Aggañña-sutta to the Mahāyāna. History of Religions, 36, 183-217. 
Gnoli, R. (1978). The Gilgit manuscript of the Sanghabhedavastu, being the 17th and last section of the Vinaya of the Mūlasarvāstivādin. Rome: Istituto Italiano per il Medio ed Estremo Oriente.

Hamilton, S. (1996). Identity and experience; the constitution of the human being according to early Buddhism. London: Luzac Oriental.

Harvey, P. (1993). The mind-body relationship in Pāli Buddhism: a philosophical investigation. Asian Philosophy, 3(1), 29-41.

Kuan, T.-F. (2008). Mindfulness in early Buddhism, new approaches through psychology and textual analysis of Pali, Chinese and Sanskrit sources. London: Routledge.

Langenberg, A. P. (2018). Buddhism and sexuality. In D. Cozort \& J. M. Shields (Eds.), Oxford handbook of Buddhist ethics (pp. 567-591). Oxford: Oxford University Press.

Lee, S. (2014). The meaning of 'mind-made body' (S. manomaya-kāya, C. yisheng shen 意生身) in Buddhist cosmological and soteriological systems. Buddhist Studies Review, 31(1), 65-90. https:// doi.org/10.1558/bsrv.v31i1.65.

Radich, M. D. (2007). The somatics of liberation: ideas about embodiment in Buddhism from its origins to the fifth century C.E. $\mathrm{PhD}$ thesis. Cambridge, Massachusetts: Harvard University, Department of East Asian Languages and Civilizations.

Radich, M. D., \& Anālayo, Bh. (2017). Were the Ekottarika-āgama 增壹阿含經 T 125 and the Madhyama-āgama 中阿含經 T 26 translated by the same person? An assessment on the basis of translation style. In Bh. Dhammadinnā (Ed.), Research on the Madhyama-ägama (pp. 209-237). Taipei: Dharma Drum Publishing Corporation.

Rhys Davids, T.W. and Stede, W. (1921/1993). Pali-English Dictionary. Delhi: Motilal Banarsidass.

Schlingloff, D. (2015). Die übermenschlichen Phänomene, visuelle Meditation und Wundererscheinung in Buddhistischer Literatur und Kunst, Ein religionsgeschichtlicher Versuch. Düsseldorf: EKŌ-Haus der Japanischen Kultur.

Schmithausen, L. (1981). On some aspects of descriptions or theories of 'liberating insight' and 'enlightenment' in early Buddhism. In K. Bruhn, \& A. Wezler (Eds.), Studien zum Jainismus und Buddhismus, Gedenkschrift für Ludwig Alsdorf (pp. 199-250). Wiesbaden: Franz Steiner.

Shulman, E. (2021). Embodied transcendence: the Buddha's body in the Pāli Nikāyas. Religions, 12(179), 1-17. https://doi.org/10. 3390/rel12030179

Swearer, D. K. (1973). Control and freedom: the structure of Buddhist meditation in the Pāli suttas. Philosophy East and West, 23(2), $435-455$.

Publisher's Note Springer Nature remains neutral with regard to jurisdictional claims in published maps and institutional affiliations. 